\title{
Metamorfozy domeny publicznej i ich janusowe oblicze społeczne
}

\section{Streszczenie}

Celem artykułu jest ukazanie niektórych tendencji w przemianach zachodzących współcześnie w domenie publicznej i zwrócenie uwagi na pewne analogie, jakie występują pomiędzy zmianami w przestrzeni miejskiej a społecznymi procesami modernizacyjnymi, które toczą się w szerszej, ogólnokrajowej skali. Oprócz wstępu i podsumowania, tekst składa się z dwóch głównych części - poświęconej ogólniejszym rozważaniom oraz empirycznej. W części pierwszej przedstawiono bardziej generalne kwestie dotyczące natury i znaczenia miejskiej przestrzeni publicznej oraz sposobów ingerowania w jej kształt, $\mathrm{z}$ uwględnieniem zwłaszcza zjawisk określanych mianem rewitalizacji i gentryfikacji. Natomiast w części drugiej, tytułem ilustracji, omówiono pokrótce trzy konkretne przypadki unowocześniających oddziaływań o różnym charakterze i skutkach, jakie wystąpily w ostatnich latach w Warszawie.

Słowa kluczowe: przestrzeń/domena publiczna, polityka publiczna, polityka miejska, rewitalizacja, gentryfikacja

\section{Metamorphoses of the Public Domain and their Janus-Faced Social Consequences}

\begin{abstract}
The aim of the article is to show some trends in contemporary transformation of the public domain, and draw attention to certain analogies that occur between changes in the urban space and social modernization processes taking place at a wider, nationwide scale. In addition to the introduction and the conclusion, the text consists of two main parts: dedicated to theoretical considerations and empirical findings. The first part presents more general issues concerning the nature and significance of the urban public space and ways of interfering in its shape, taking into account in particular the phenomena referred to as revitalization (urban renewal) and gentrification. In the second part, for
\end{abstract}


illustrative exemplification, three specific cases of modernizing impacts of various nature and effects that took place in recent years in Warsaw were briefly discussed.

Keywords: public space/domain, public policy, urban policy, urban renewal/regeneration, gentrification

Jeden z najwybitniejszych współczesnych badaczy polityki publicznej na świecie, amerykański politolog B.G. Peters (2015), porównuje jej projektowanie i wcielanie w życie do architektury i inżynierii, zaś powinności przypisywane polityce - do zadań stawianych architektom i inżynierom. Wyróżnia w tym kontekście trzy zasadnicze komponenty procesu public policy making: 1) zrozumienie przyczyn i istoty rozwiązywanego problemu, 2) dobór środków i instrumentów oczekiwanej czy wymaganej interwencji, 3) ewaluację podjętych działań. Architektoniczno-inżynierskie skojarzenia przy okazji analizowania polityki publicznej nie są czymś rzadkim ani wyjątkowym. Interpretacja nawiązująca do inżynierii, cyklu produkcyjnego lub taśmy montażowej w fabryce to - obok ujęć scenicznego i sieciowego - jeden z trzech zasadniczych paradygmatów, w jakich można postrzegać i badać działania polityczne w różnej skali (Anioł, 2018).

Sami politycy często upatrują swoją misję w kreowaniu, zarządzaniu, porządkowaniu i przekształcaniu domeny (przestrzeni) publicznej. Z urbanistami, architektami i inżynierami łączy ich podobny zamysł planowania i świadomego odziaływania na rzeczywistość, zarówno tę fizyczną, materialną, jak i społeczną, symboliczną. Stąd też obecność i popularność w języku politycznym takich pojęć jak: projektowanie, inżynieria społeczna, socjotechnika, technologia polityczna. W architekturze i urbanistyce politycy często widzą rodzaj władzy, instrumenty zmieniania świata, w założeniu - na lepsze (zob. np. Sudjic, 2015; Burno, 2016; Ciarkowski, 2017). Imponować im może ten sposób wpływania na rzeczywistość, który jest bardzo realny, bo namacalny i lepiej widoczny gołym okiem. I stosunkowo szybki, bo droga od projektu do jego realizacji jest $\mathrm{z}$ reguły krótsza i prostsza niż $\mathrm{w}$ wypadku implementowania wielkich planów, strategii i wizji politycznych. Atrakcyjne może tu więc być znacznie większe poczucie sprawczości, którego politycy mogą zazdrościć architektom i urbanistom.

$Z$ drugiej strony, wielu - jeśli nie większość - urbanistów i architektów jest przekonanych, że to, co niedoskonałe w człowieku i społeczeństwie, może być poprawiane przez otoczenie materialne: kształt budynków, układ ulic i placów, wygląd mieszkań, infrastrukturę komunikacyjną, organizację miejskiej przestrzeni publicznej. Relacje i życie zbiorowe są blisko związane ze sposobem zabudowania i urządzenia przestrzeni fizycznej (Gehl, 2009). Dwie sfery rzeczywistości: czysto fizyczna oraz społeczna przenikają się i mocno oddziałują na siebie (Anioł, 2016). Materialny ład 
przestrzenny, w jakim żyją zbiorowości - podobnie jak ład społeczny, który one tworzą i którego doświadczają na co dzień - są takim samym dobrem wspólnym.

Wizję architektury głęboko osadzonej w kontekście społecznym miał m.in. Le Corbusier, papież modernizmu i twórca bardzo wszechstronny, bo niezależnie od projektowania domów był równocześnie malarzem, rzeźbiarzem, pisarzem i wykładowcą, także kimś, kogo dzisiaj potocznie zwykło się nazywać celebrytą. Prezentował całościowe (holistyczne) podejście do budowania i kształtowania przestrzeni: obok formy, stylu architektonicznego i walorów estetycznych liczyły się dla niego także kwestie inżynierii ruchu i transportu, usług publicznych, zdrowia, mieszkalnictwa, gęstości zaludnienia i zabudowy, jakości życia, a więc liczne zagadnienia ekonomiczne, społeczne, polityczne i zgoła filozoficzne, które tworzą szerszy kontekst architektury. Była ona dla niego czymś daleko więcej niż tylko - paradoksalnie trochę wbrew sformułowanej przez siebie samego zawężającej definicji - „przemyślaną, bezbłędną, wspaniałą grą brył w świetle" (Le Corbusier, 2012: 80). Le Corbusier poszukiwał kodu optymalnego otoczenia człowieka (Flint, 2017: 294 i nast.). W tym sensie, można powiedzieć, przypominał wielu polityków, zwłaszcza tych o szczególnie rozwiniętych, wybujałych aspiracjach i silnym poczuciu misji.

Znamienne i interesujące są w szczególności daleko idące analogie i związki między przemianami zachodzącymi w ramach osiedli ludzkich a szeroko rozumianym rozwojem społecznym. Zmiany w obu tych sferach odbywają się według podobnych reguł, oddziałują nań ośrodki władzy publicznej i cała gama innych, tych samych lub porównywalnych czynników. Proces miastotwórczy, czyli kształtowanie się i ewolucja miast, $w$ tym występujących tam form urbanistycznych i przestrzeni publicznych, jest pewną wersją, jedną z ograniczonych do mniejszej skali postaci rozwoju społecznego. W obu dziedzinach można dopatrywać się zbliżonych do siebie, pokrewnych cech, wyzwań, dylematów i tendencji.

Niniejszy artykuł skupia uwagę na treści i konsekwencjach działań modernizacyjnych, jakie podejmowane są w domenie publicznej. Jego celem jest zwrócenie uwagi na podobieństwa łączące współczesne przekształcenia w przestrzeni miejskiej z ogólniejszymi tendencjami w społecznych proceach modernizacyjnych, jakie zachodzą w skali ogólnokrajowej. Tekst ma dwie główne części: poświęconą ogólniejszym rozważaniom oraz empiryczną. W części pierwszej omówiono bardziej generalne kwestie dotyczące natury i znaczenia miejskiej przestrzeni publicznej oraz sposobów ingerowania $\mathrm{w}$ jej kształt, $\mathrm{z}$ uwględnieniem zwłaszcza zjawisk określanych mianem rewitalizacji i gentryfikacji ${ }^{1}$. Natomiast w części drugiej przedstawiono pokrótce

1 Według najogólniejszej definicji słownikowej gentryfikacja oznacza „zmianę charakteru części miasta w bardziej skomercjalizowaną, zdominowaną przez osoby o wyższym statusie materialnym” 
trzy konkretne przypadki unowocześniających oddziaływań o różnym charakterze i skutkach, jakie wystąpiły w ostatnich latach w Warszawie.

\section{Dyskusyjne następstwa modernizacji}

Bliższa obserwacja zmian modernizacyjnych dokonujących się ostatnio w przestrzeniach miejskich nasuwa m.in. następujące pytania: Czy każda odnowa miasta musi pociągać za sobą gentryfikację? Czy jesteśmy na nią skazani? Czy w ogóle i ewentualnie jak można przed nią uciec? Czy i w jaki sposób daje się jej zapobiegać? Czy rewitalizacja, remont starych i zaniedbanych kamienic musi oznaczać wysiedlanie na stałe mieszkających w nich dotąd ludzi - tak jak to się stało np. w obecnej dekadzie w śródmieściu Łodzi. Podobne wyzwanie jest teraz aktualne w poddawanej rewitalizacji warszawskiej dzielnicy Praga, gdzie już wiadomo, że nie wszyscy po remontach wrócą do swoich domów². Czy, pytając ogólniej, każda próba uszlachetnienia przestrzeni miejskiej musi prowadzić do triumfu pieniądza i kończyć się wypieraniem z niej ludzi uboższych i słabszych, musi wywoływać społeczną segregację, napięcia identyfikacyjne, a nawet niszczyć wspólnotę lokalną i jej tradycyjną tożsamość?

I jeszcze jedna kwestia: jak w kontekście procesów komercjalizacji i prywatyzacji miejskiej przestrzeni - czego przejawem jest np. powstawanie wielkich galerii handlowych, odgradzanie się od otoczenia enklaw dostatku i luksusu - wygląda sprawa redefiniowania na nowo granic między dwiema sferami: publiczną i prywatną? Jak zmienia się zakres domeny publicznej w warunkach przekształcenia struktury miejskiej, postrzeganej w perspektywie sieciowej? (Hajer i Reijndorp, 2001).

Kiedy przenosimy wskazane kwestie i wyzwania do realizowanej w skali całego kraju polityki publicznej, nasuwać się mogą w szerszym sensie i kontekście analogiczne pytania o bardziej uniwersalnym charakterze: Czy unowocześnianie struktur społecznych, gospodarki czy państwa musi nieuchronnie wiązać się z istotnymi kosztami społecznymi, w szczególności zaś musi bezwzględnie prowadzić do narastania nierówności i wykluczania ze wspólnego życia mniej zamożnych grup? Czy pauperyzacja, prekaryzacja i marginalizacja „przegranych” to nieunikniony produkt uboczny wszystkich głębszych reform? Jeszcze inaczej pytając: Czy każda modernizacja jest

(Słownik Języka Polskiego PWN). Więcej uwag terminologicznych i przybliżających to zjawisko zawiera dalsza część artykułu.

2 Socjolog Paweł Możdżeński (2017) z Instytutu Stosowanych Nauk Społecznych UW, oceniając bolesne, jak podkreśla, procesy rewitalizacji zachodzące na warszawskiej Pradze, w szczególności zaś zastanawiając się nad przyszłym losem mieszkańców remontowanych tam kamienic, pesymistycznie deklaruje: „Nie wierzę w rewitalizację bez gentryfikacji”. 
równoznaczna z polaryzacją, ze wzrostem podziałów dochodowych, różnic w statusie i ekskluzją społeczną tych, którym się nie powiodło lub którzy słabiej odnajdują się w nowych warunkach i czasach? Czy zawsze muszą być zwycięzcy i przegrani? To znaczy ci pierwsi, beneficjenci, na ogół hojniej wyposażeni już na samym starcie w najróżniejsze kapitały (finansowe, polityczne, kulturowe i społeczne), a z drugiej strony - pozbawione tych zasobów i przywilejów ofiary transformacji? Jaki może być i jest wpływ programów modernizacyjnych na identyfikację społeczną i kulturową doświadczanych przez owe zmiany grup obywateli i poszczególnych jednostek? Jaka jest tu rola polityki tożsamości (identity politics)?

W nawiązaniu do wielkiego planu urbanistycznej transformacji Paryża na początku drugiej połowy XIX w., jaką przeprowadził baron G.-E. Haussmann, projekty unowocześniania wielu współczesnych metropolii są określane mianem neohaussmannizacji. Używający tego pojęcia, nazywający sam siebie „metromarksistą”, A. Merrifield z Uniwersytetu w Cambridge utożsamie je w swojej dość radykalnej interpretacji z grabieżczym, pasożytniczym i opresyjnym modelem rozwoju miast. Procesy słabo kontrolowanej prywatyzacji, spekulowania nieruchomościami, wyprzedawania majątku publicznego, a jednocześnie zadłużania miast, segementacji dzielnic według statusu mieszkańców, zanikania przestrzeni wspólnych i infrastruktury społecznej itp. są według tego badacza przejawami poszukiwania oraz wykorzystywania nowych źródeł zysku i akumulacji kapitału przez wielki biznes, który w tym celu wchodzi $\mathrm{w}$ powiązania i sojusze $\mathrm{z}$ wpływowymi środowiskami np. prawników czy wyższej biurokracji, zarówno tej miejskiej, jak i osadzonej w instytucjach centralnej administracji państwowej (Merrifield, 2016).

Nawet gdyby uznać, że obraz miejskich zmian jest w ujęciu Merrifielda przerysowany, zbyt jednoznaczny i za mało wyważony, to uprawnione wydaje się mówienie o podobnych tendencjach występujących w ramach metropolii, jak i państw. Przemiany zachodzące w miejskiej substancji materialnej i przestrzeni publicznej - w tym na skutek świadomie podejmowanych działań rewitalizacyjnych lub bardziej żywiołowo przebiegającej gentryfikacji - pod wieloma względami przypominają bowiem ogólniejszą zmianę społeczną, szersze procesy ekonomicznej, kulturowej i politycznej modernizacji. Także te dokonujące się w skali całego kraju w ostatnich trzech dekadach w Polsce pod hasłem demokratycznej, liberalnej i wolnorynkowej transformacji.

Można by zaryzykować tezę, że jedna ze słabszych stron kompleksowej modernizacji, która objęła Polskę w okresie po 1989 r., polegała na tym, że - używając w tym miejscu języka typowego dla polityki miejskiej i urban studies - we wspomnianym procesie, który można by metaforycznie nazwać „rewitalizacją kraju”, w znacznym stopniu zaniedbano, zlekceważono czy też przoczono wiele niekorzystnych konsekwencji 
społecznych towarzyszących głębokim zmianom, a więc coś, co zbiorczo i umownie, nie tylko symbolicznie, można by z kolei określić mianem „makrogentryfikacji”. Chodzi przede wszystkim o te negatywne skutki uboczne przemian, jakimi stały się nowe podziały społeczne i formy marginalizacji. Kwestią nie w pełni docenioną w III Rzeczypospolitej okazały się również związane z reformami i odnową problemy tożsamościowe. Zaowocowały one napięciami o charakterze kulturowym, kłopotami i deficytami związanymi z identyfikacją grupową - a więc tym wszystkim, co ułatwiło m.in. obserwowane ostatnio w Polsce ożywienie nastrojów i postaw nacjonalistycznych.

Nie rozwijając szerzej ani nie uzsadniając dalej powyższych hipotez, ze względu na objętościowe ograniczenia artykułu, skoncentruję się teraz na metamorfozach miejskich przestrzeni publicznych.

\section{Domena publiczna w mieście i jej znaczenie}

Według J. Habermasa, sfera publiczna to miejsce, w którym ogół obywateli, niezależnie od pochodzenia, statusu społecznego czy stopnia zamożności, aktywnie włącza się w proces polityczny. Do tworzenia i funkcjonowania wspólnej przestrzeni publicznej - politycznej, ekonomicznej i kulturowej - w której ludzie razem ze sobą żyją, pracują, decydują o wspólnych sprawach, uzgadniają ze sobą rozbieżne interesy itp., sprowadza się w klasycznym, najszerszym ujęciu ogólna idea miasta (Nawratek, 2008). Ogólnodostępna przestrzeń publiczna w mieście jest najważniejszym tradycyjnym zwornikiem i spoiwem jego mieszkańców, odgrywa kluczową rolę miastotwórczą.

Francuski myśliciel i przenikliwy analityk amerykańskiej demokracji A. de Tocqueville utożsamiał miasto $\mathrm{z}$ wolnością, której - jak wywodził - w prywatnych, zamkniętych enklawach "nie widać”, ujawnia się ona dopiero w otwartych, obywatelskich przestrzeniach publicznych. Znany współczesny amerykańsko-brytyjski socjolog R. Sennett lubił podkreślać w swoich książkach, że najważniejszą funkcją miasta jest umożliwianie obcym ludziom spontanicznych, naturalnych spotkań. Dlatego planowanie miejskiej przestrzeni powinno im to ułatwiać, a nie utrudniać (Sennett, 1996). Inny amerykański socjolog R. Oldenburg, twórca teorii tzw. miejsc trzecich w mieście, czyli znajdujących się poza domem i pracą, przekonywał, że powinny być one maksymalnie dostępne, tzn. jeśli nie w ogóle darmowe, to przynajmniej relatywnie niedrogie.

W sensie fizycznym, materialnym miejska przestrzeń publiczna to ten fragment ogólnej przestrzeni miejskiej, w którym poruszamy się po opuszczeniu naszych prywatnych mieszkań i domów. Mówiąc konkretniej, to ta część struktury urbanistycznej, która obejmuje ulice, chodniki i deptaki, place, bulwary i nadrzeczne promenady, 
parki i zieleńce, estakady, mosty i ścieżki rowerowe, place zabaw dla dzieci, sklepy, kawiarnie, dworce, stadiony i inne obiekty sportowe, muzea, biblioteki, szkoły, przychodnie oraz inne placówki i lokale usługowe.

Wedle polskich regulacji ustawowych z 2003 r., przestrzeń publiczną stanowi „obszar o szczególnym znaczeniu dla zaspokojenia potrzeb mieszkańców, poprawy jakości życia i sprzyjający nawiązywaniu kontaktów społecznych ze względu na jego położenie oraz cechy funkcjonalno-przestrzenne, określony w studium uwarunkowań i kierunków zagospodarowania przestrzennego gminy" (Ustawa o planowaniu..., 2003). Ograniczenie sformułowane na końcu tej bardzo urzędowej definicji w istocie zawęża tę przestrzeń tylko do formalnie i punktowo oznaczonych fragmentów planu danej miejscowości.

Szczególną rolę wśród tych publicznych miejsc odgrywają przy tym (powinny odgrywać) place jako węzłowe punkty w tkance miejskiej. W założeniu pełnią one ważne funkcje handlowe, obywatelskie, kulturowe, symboliczne. Prowokują przemieszczających się po mieście ludzi do zatrzymania się i kontaktu z innymi, wymiany informacji i wrażeń, spotkania $\mathrm{z}$ innością. To także dogodne miejsce dla spontanicznych i zorganizowanych zgromadzeń. Rynki lub centralne place stanowią symboliczne serca organizmów miejskich, to tam puls miasta bije najmocniej.

Miejska przestrzeń publiczna wypełnia i dopełnia strefy zlokalizowane między enklawami prywatności, skłania do kontaktów międzyludzkich i aktywnego spędzania wolnego czasu, rekreacji, obserwowania innych osób i przyrody. Pomaga tworzyć wspólnotę, socjalizuje i „klei” ludzi ze sobą, niezależnie od odmiennej płci, wieku, stanu zdrowia czy zasobności portfela. Łączy młodszych i starszych, w pełni zdrowych i niepełnosprawnych, silnych i słabszych, bogatych i biednych. Przecinają się w niej trasy przedstawicieli różnych warstw, mieszkańców mniej i bardziej zamożnych osiedli i dzielnic miasta, dzieci chodzących do gorszych i lepszych szkół. To tu, w strefach nielimitowanego dostępu i niekontrolowanego przepływu osób, wykluwają się nowe, nieformalne relacje. Częstszy i bardziej intensywny bezpośredni kontakt buduje poczucie przynależności, zacieśnia więzi społeczne, stwarza przesłanki dla solidarnego i skuteczniejszego osiągania wspólnych celów w drodze współpracy. Bliższe sąsiedztwo wzmacnia lokalne społeczności, buduje tożsamość i identyfikację z miejscem zamieszkania albo dłuższego pobytu (Franta, 2004; Jastrząb, 2004; Ledwoń, 2007; Pluta, 2012).

Przestrzeń publiczna niweluje zatem społeczną hierarchię, pozwala mieszać się ze sobą ludziom, nikogo nie wywyższając (podczas gdy np. w miejscu pracy jest szef i podwładny, w szkole nauczyciel i uczeń itd.). Tworzy społeczność równych sobie obywateli, bardziej egalitarną, sprawiedliwą i inkluzywną. Tam, gdzie jest najwięcej niedostępnych fragmentów miasta, np. grodzonych osiedli, nierówności społeczne 
znajdują najlepsze warunki dla reprodukcji, słabnie wzajemna tolerancja i najpełniej rozkwita populizm.

Kluczowa w tym kontekście wydaje się właśnie inkluzywność ładu przestrzennego, maksymalna dostępność domeny publicznej dla każdego jej użytkownika, dla wszystkich zainteresowanych uczestników życia społecznego, a nie tylko dla wybranych, nielicznych, jakiejś elity lub kasty. Używane niekiedy pojęcie „demokracji przestrzennej” podkreśla, z jednej strony, udział mieszkańców w kształtowaniu przestrzeni miejskiej, a z drugiej - kwestię dostępności, ułatwień urbanistyczno-architektonicznych, które sprzyjają nawiązywaniu relacji społecznych w miastach. Demokratyczne "miasto dla wszystkich" najlepiej realizuje interes publiczny, sprzyja podnoszeniu jakości życia mieszkańców, zwiększaniu ich dobrostanu, wygody i bezpieczeństwa.

Kryzys, czyli degradacja, degenerowanie się i dewastacja miejskiej przestrzeni publicznej to przede wszystkim ograniczanie jej zakresu oraz powszechnej do niej dostępności, przez co traci ona w ten sposób samą swą istotę i najgłębszy sens. Działania antykryzysowe i naprawcze zmierzają zatem do poszerzania możliwości swobodnego użytkowania przestrzeni przez członków danej zbiorowości, do usuwania pojawiających się barier w dostępie o najróżniejszym charakterze: finansowym (czynnik zamożności), architektonicznym (np. dla niepełnosprawnych), komunikacyjnym (utrudniony dojazd), ekologicznym (narażenie na smog, ulewę, mróz), w zakresie bezpieczeństwa (stopień zagrożenia przestępczością, przemocą, wypadkiem komunikacyjnym), symbolicznym (utrata poczucia identyfikacji).

W praktyce i konkretnie rzecz dotyczy np. możliwości korzystania przez osoby niepełnosprawne z chodników, przejść dla pieszych, przystanków, miejsc parkingowych, toalet publicznych. Idzie też o usuwanie zbędnych przeszkód w poruszaniu się po mieście przez seniorów, rodziców z małymi dziećmi, spacerujących z psami, amatorów sportu czy rowerzystów. W grę wchodzą takie rozwiązania, jak dodatkowe zebry malowane na jezdni, podjazdy i windy, obniżone krawężniki, niebieskie „koperty” na parkingach, lepsze oświetlenie, ławki na skwerach i w parkach, wypukłe plany peronów dla niewidomych na stacjach metra itp. ${ }^{3}$.

Osobną sprawą jest problem tzw. architektury wykluczającej, ograniczającej powszechny dostęp do przestrzeni publicznych i wypierającej z niej osoby mniej zamożne lub np. bezdomnych. Stąd m.in. zamykanie na noc parków miejskich, śmietników i kubłów śmietnikowych na kłódkę. W podobnym celu w niektórych europejskich miastach montowane są betonowe kolce pod mostami i kładkami dla

\footnotetext{
3 Poprawie podobnej inkluzywności ma służyć specjalne zarządzenie prezydent Warszawy z $2017 \mathrm{r}$. pt. „Standardy dostępności” (Karpieszuk, 2017).
} 
pieszych. Pierwsze przystanki z węższymi i lekko wypukłymi ławkami, by nie można była na nich koczować, pojawiły się już w Warszawie.

\section{Rewitalizacja i gentryfikacja}

Rewitalizacja dotyczy zarówno architektonicznego, jak i urbanistycznego wymiaru zdegradowanej przestrzeni miejskiej. Chodzi o ożywienie i rewaloryzację w obu tych sferach. Czasem ów proces jest redukowany tylko do estetyzacji (tj. estetycznej odnowy) przestrzeni, do usuwania wizualnej szpetoty oraz renowacji budynków i ulic. Ale najczęściej chodzi też przecież o wprowadzanie nowych zasad i mechanizmów funkcjonowania określonych dzielnic lub fragmentów miasta, np. o ich humanizację, o bardziej zrównoważone zaspokajanie przez nie starych i nowych potrzeb mieszkańców, o lepszą integrację różnych układów i dziedzin życia. O przywracanie przestrzeni miejskiej pożądanej wielofunkcyjności (Skalski, 2009).

Rewitalizacja obejmuje więc nie tylko zmiany materialne, ale i społeczne (Frąckiewicz, 2004). Chodzi o rozwiązanie nie tylko problemów infrastrukturalnych, ale i socjalnych (zwalczanie wykluczenia i patologii, programy reintegracji zawodowej, tworzenie świetlic środowiskowych itp.). W tym sensie może być traktowana jako rodzaj polityki rozwoju albo modernizacji w skali lokalnej. Termin urban renewal (miejska odnowa) został ukuty w USA w połowie lat 50. XX w., w związku z programami modernizacji wielu amerykańskich miast, które zakładały poważne, dotowane przez państwo wyburzenia obszarów śródmiejskich. Działania te zostały powiązane z budową tam mieszkań komunalnych i prywatnych wieżowców, a także wielopasmowych przelotówek łączących centra z przedmieściami i siecią międzystanowych autostrad, której powstanie przewidziała i wsparła specjalna ustawa z 1956 r. ${ }^{4}$.

Z kolei gentryfikacja - to termin zaklęcie o mniej pozytywnym wydźwięku niż rewitalizacja, przy czym opisuje on proces bardziej żywiołowy, mimowolny i w zasadzie raczej nieplanowany, w odróżnieniu od z reguły intencjonalnie organizowanych programów miejskiej odnowy, będących formą i próbą świadomego interweniowania $\mathrm{i}$ ingerowania $\mathrm{w}$ przestrzeń publiczną.

Zjawisko to zostało po raz pierwszy poddane głębszej analizie przez brytyjską badaczkę R. Glass, na przykładzie przeobrażeń zachodzących na przełomie lat 50. i 60. XX w. w dawnej dzielnicy doków w Londynie (Glass, 1964). Natomiast teoretyczna refleksja nad tym zjawiskiem sięga lat 70. XX w. (Smith, 1979, 1996; Lees,

4 Podpisany przez prezydenta D. Eisenhowera Federal Aid Highway Act podniósł udział dotacji federalnych w budowie autostrad i obwodnic do 90 proc. wartości tych inwestycji. 
Slater i Wyly, 2008). Termin gentrification, wywodzący się ze słowa gentry (szlachta), na język polski można by dosłownie przetłumaczyć jako „uszlachetnianie”, ale bywa też przekładane jako „uburżuazyjnienie” (Olszewski, 2010: 93). Pojęcie to pierwotnie miało niekorzystny, ironiczny lub wręcz pejoratywny wydźwięk, z czasem jednak $\mathrm{w}$ wielu interpretacjach zaczęło ono nabierać także pozytywnego zabarwienia znaczeniowego. Zależnie od tego, czy eksponowane są korzystne czy negatywne aspekty całego procesu, czy postrzega się go przede wszystkim krytycznie czy afirmatywnie, zmienia się także odpowiednio semantyczny odcień omawianej kategorii. Warto więc w sumie postrzegać ją w perspektywie szans i zagrożeń (Skalski, 2017).

Plusem gentryfikacji wydaje się przede wszystkiem podniesienie jakości, atrakcyjności i prestiżu zaniedbanego wcześniej miejsca, estetyzacja przestrzeni, podwyższenie standardu domów i mieszkań, ekonomiczne zyski związane z ożywieniem rozwoju danej dzielnicy, choć rozkład tych korzyści bywa na ogół nierównomierny.

Minusem gentryfikacji jawią się zaś niektóre niekorzystne następstwa społeczne dokonujących się zmian, związane z komercjalizacją i ekonomizacją odnawianej przestrzeni (Lorens i Ratajczyk-Piątkowska, 2008), z ograniczaniem do niej dostępności, ze wzrostem napięć i konfliktów z grupami napływowymi o wyższych dochodach i statusie społecznym, $\mathrm{z}$ wymuszaniem na rdzennych mieszkańcach danego rejonu przesiedleń $w$ inne miejsca. Chodzi zatem o zagrożenie niedobrowolną wymianą ludności, o zaburzanie i nadwerężanie tradycyjnych więzi, o niebezpieczeństwo rozbijania lokalnych społeczności, o spychanie słabszych grup i ich problemów na margines lub zgoła w inne miejsce. Czasem mówi się w tym kontekście o „czyszczeniu” lub „czystce socjalnej” jako koszcie ubocznym procesu rewitalizacji. Rzecz dotyczy również likwidowania różnorodności - nie tylko w strukturze społecznej, ale też świadczonych na danym terenie usług. Przykładem może być dość mechaniczne ujednolicanie określonego obszaru pod kątem jego nowych, zawężonych funkcji, np. turystyczno-rozrywkowych, co bywa nazywane „turystyfikacją”.

Cykl gentryfikacyjny ma na ogół następujący przebieg. Zainteresowanie pewnym rejonem miasta okazują najpierw ludzie kultury, artyści, studenci. Potem włączają się w ów proces prywatni inwestorzy i władze miejskie, aż w końcu na danym obszarze zaczynają dominować i wyznaczać priorytety, narzucać swoją hierarchię potrzeb najbardziej zasobni użytkownicy i klienci. A więc zjawisko zrazu obiecujące i pozytywne, kiedy nabiera wewnętrznej dynamiki - i zaczyna być napędzane swoją specyficzną logiką - pokazuje z czasem także swą mniej urodziwą twarz. Tę prawidłowość dobrze ilustrują analizowane przez badaczy i ekspertów procesy zachodzące w wielu miejscach na świecie, choćby w miastach tak różnych jak Berlin i Nowa Huta (Groyecka, 2014; Gądecki, 2012). 
Podsumowując można więc przyjąć, że gentryfikacja to szczególny rodzaj, specyficzna postać i przypadek rewitalizacji przestrzeni miejskiej, w którym podnoszenie kosztów życia w odnowionej dzielnicy (lub jakiejś jej części) nie tylko pogarsza warunki bytu niektórych grup autochtonów, nie tylko prowadzi do nowych podziałów społecznych i do zmian w strukturze mieszkańców, ale też w konsekwencji degeneruje bądź nawet niszczy jej dotychczasową tożsamość i habitat (Jadach-Sepioło, 2009).

\section{Trzy metamorfozy w Warszawie}

Przyjrzymy się teraz trzem znamiennym, szczególnie ilustratywnym przypadkom przekształceń, jakim ulegały w ostatnich pięciu latach dobrze znane i chętnie odwiedzane fragmenty warszawskiej przestrzeni publicznej. Przytoczone empiryczne egzemplifikacje można potraktować jako przejawy i zwierciadło ogólniejszych tendencji w społecznych procesach modernizacyjnych, które toczą się w Polsce na poziomie całego kraju.

1. Pierwszy z przykładów - casus odnowionej Hali Koszyki - dobrze pokazuje powiązanie rewitalizacji obiektu z ewolucją jego podstawowej funkcji: od publicznej w węższym rozumieniu do zdecydowanie bardziej - w opinii niektórych nawet czysto - komercyjnej. Pod względem stylistycznym obecna, nieco hybrydalna Hala wprawdzie nawiązuje do pierwowzoru, ale w istocie jest nową budowlą, powstałą w wyniku rozbiórki zabytku i ponownego złożenia wybranych jego starych, oryginalnych elementów, które wyeksponowano i potraktowano teraz jako ozdobne dekoracje. Obok entuzjastycznych komentarzy mówiących o w sumie bardzo udanej rewitalizacji, nie brakuje również surowych krytyków tego projektu, uznających starą-nową Halę za inwestycyjną porażkę i modelowy przykład gentryfikacji, naznaczonej na dodatek imitacyjno- kosmopolitycznym sznytem.

2. Dalej, w reaktywowanej niedawno Hali Gwardii, zdaniem wielu recenzentów, można ujrzeć alternatywny, pozytywny kontrprzykład czy kontrapunkt do poprzedniego przypadku. Rewaloryzując ów obiekt, wykazano się - jak się wydaje - znacznie większym wyczuciem, dbałością i szacunkiem dla związanej z tym miejscem lokalnej, miejskiej tradycji. Powstał rodzaj zmiksowanego, wielkomiejskiego, ale jednak bazaru, który nie olśniewa, nie bije po oczach nowoczesnością, a tym bardziej luksusem, nie pręży się dumnie, ale sprawnie, rzetelnie, skutecznie i z wdziękiem odgrywa wyznaczone role publiczne: handlową, gastronomiczną i kulturalną.

3. Trzeci przykład dotyczy placu Zbawiciela, w którego wielowarstwowej przestrzeni doszło w pierwszej połowie obecnej dekady do znamiennej kolizji wartości, 
przekonań i konfrontacji rozbieżnych postaw, w związku z pojawieniem się w niej kontrowersyjnej instalacji artystycznej w postaci wielobarwnej tęczy. Ujawniony wokół tego zdarzenia, symbolicznie i dosłownie rozpalony konflikt można potraktować jako ilustrację pewnej szczególnej sytuacji modernizacyjnej, a mianowicie zderzenia pluralistycznej nowoczesności z antyliberalnym, zdradzającym autorytarytarne pokusy i tęsknoty tradycjonalizmem. W widowiskowym podpalaniu tęczy na tymże placu być może dałoby się także zobaczyć drobny, acz symboliczny symptom i zwiastun nadciągającej od pewnego czasu nad Polskę i cały świat zachodni fali zmian, którą określa się czasem mianem konserwatywnej kontrrewolucji kulturowej.

\section{Od publicznej hali targowej do prywatnej gastrogalerii - przypadek Hali Koszyki}

Hala Koszyki, jako klasyczna miejska hala targowa, powstała pierwotnie w 1909 r. na działce zakupionej przez magistrat i na podstawie projektu Juliusza Dzierżanowskiego, późniejszego naczelnego architekta Warszawy. Podobnie jak wybudowane wcześniej w mieście dwie Hale Mirowskie (w latach 1899-1901), nie była placówką ściśle komercyjną, lecz raczej miejską instytucją użyteczności publicznej, mającą na celu uporządkowanie handlu i zapewnienie mieszkańcom śródmieścia zaopatrzenia w podstawowe artykuły spożywcze. Pod względem przeznaczenia przypominała podobne obiekty, nazywane wówczas „brzuchami miast”, a spotykane na początku ubiegłego wieku m.in. w Paryżu i Londynie. Miała służyć zaspokajaniu potrzeb mieszkańców na trochę podobnej zasadzie jak dworce kolejowe, centralny szpital miejski, sieć wodno-kanalizacyjna, muzea czy filharmonia, tyle że w innej, specyficznej dla siebie dziedzinie. Warto podkreślić, że była to wtedy inwestycja bardzo nowoczesna pod względem technicznym: stoiska miały bieżącą wodę, posadzki i ściany wyłożono ceramiczną okładziną, w piwnicach były chłodnie itp.

Stylistycznie ta swoista „świątynia handlu” przypominała nieco trzynawową bazylikę. Wpisując się w modernizm jako artystyczny nurt nowej sztuki europejskiej z przełomu XIX i XX w., hala czerpała inspiracje z ducha secesji, co podkreślały dwa imponujące okrągłe portale na głównym budynku oraz secesyjne płaskorzeźby z piaskowca, autorstwa Zygmunta Otto, jakimi udekorowano dwie murowane, obłożone czerwoną cegłą klinkierową, oficyny wejściowe wysunięte w stronę ul. Koszykowej.

W zasadzie tylko te dwa skrzydła - pawilony bramne pozostały na miejscu, gdy Halę Koszyki niemal w całości rozebrano w latach 2008-2009. Nowym właścicielem nieruchomości została w 2012 r. holenderska firma Griffin Real Estate i ona jako inwestor zadecydowała o odbudowie i przebudowie hali, zlecając zaprojektowanie 
całego przedsięwzięcia znanej pracowni JEMS Architekci. Po częściowym demontażu, odbudowie i przebudowie przez prywatnego inwestora, w nowej odsłonie Hala Koszyki została reaktywowana w październiku 2016 r. Ostatnia metamorfoza tego zabytkowego obiektu, niezależnie od aspektów własnościowych, ma dwa odrębne główne wymiary: użytkowo-funkcjonalny oraz czysto stylistyczny, aczkolwiek można dostrzec pomiędzy nimi pewne istotne powiązania.

Przebudowana Hala Koszyki wyraziście pokazała nie tylko nową jakość stylistyczną, ale i nowe funkcje obiektu, do których w gruncie rzeczy dostosowano projekt architektów. Prywatny właściciel, co można zrozumieć, postawił na cele komercyjne, a nie targowe. Opłacalność handlowania artykułami spożywczymi na tak dużej powierzchni musiała wydawać się mu wątpliwa, zwłaszcza gdy wziąć pod uwagę konkurencję sieciowych supermarketów. Zatem Koszyki (jak się utarło mówić) przestały być $\mathrm{w}$ istocie miejskim targowiskiem czy bazarem, stały się zaś przede wszystkim mekką gastronomiczną. W hali mieszczą się dziś głównie restauracje, bary, kawiarnie i knajpki, zwane dziś modnie i częściej „konceptami”, choć jest i kilka sklepów, nie tylko spożywczych, w tym supermarket Piotr i Paweł w podziemiu. Zasadniczo króluje tu jednak teraz jedzenie.

Krytycy uważają, że Koszyki przekształciły się dzisiaj w mało egalitarny, wręcz luksusowy food court dla zamożnej klienteli, w „wielki świat” dla ludzi wybranych, dla czterdziestolatków z kasą i klasą, dla różnej maści freelancerów i koneserów, bywalców i snobów, dla wytrawnych smakoszy prosecco, ostryg, krabów i krewetek. Wygląda na to, że miłośnicy brunchów i lunchów wyparli z tej przestrzeni tzw. zwykłych ludzi, prostych klientów, ale i kupców, kramarzy w białych fartuchach, przekupki i kwiaciarki. W ten sposób miano by uśmiercić jeden z najbardziej tradycyjnych, lokalnych fragmentów śródmiejskiej przestrzeni handlowej.

W każdym razie handel i usługi gastronomiczne na nowych Koszykach odbywają się teraz w wersji dalekiej od bardziej demokratycznych form występujących poprzednio lub wciąż znanych np. z Hali Mirowskiej czy pchlego targu ZOO Market na Pradze. Dzisiejsza oferta jest adresowana, jeśli nawet nie do bogaczy i krezusów, to jednak nie do biedniejszych i starszych okolicznych mieszkańców, dobrze jeszcze pamiętających wcześniejszą postać Koszyków, a którym obecnie może brakować np. straganu ze świeżą i tanią pietruszką, szczypiorkiem, nowalijkami, kwiatami czy jajami. Dawne miejsce stosunkowo tanich zakupów dla zwykłych, przeciętnych ludzi, przede wszystkim zamieszkałych w najbliższym sąsiedztwie, przekształciło się w wielkomiejski, dość elitarny przybytek dla generalnie zamożniejszych i raczej młodszych klientów.

Dzisiaj w dużo mniej swojskiej, sprywatyzowanej gastrogalerii widać przede wszystkim fascynację wzorami zagranicznymi, tym, co można spotkać w innych 
krajach europejskich. Hala przypomina podobne obiekty w Berlinie, Londynie i Paryżu, w Oslo, Madrycie czy Lizbonie, niektórzy sugerują, że równie dobrze mogłaby się nazywać Koszyki Hall. Jednym z wzorców i źródeł inspiracji mogła tu być chociażby stojąca w porcie, najstarsza hala targowa w Helsinkach, w której na wagę kupuje się krewetki i kawior, ale w której połowa stoisk to jednak już eleganckie lunchownie. Albo sztokholmska Oestermalms Saluhall, spełniająca równie połączone funkcje handlowo-gastronomiczne. Tyle że w obu nordyckich przypadkach rewitalizacja miała bardziej zachowawczy charakter, do tego stopnia, że w obu halach utrzymano nawet pierwotne kształty straganów. Tradycyjne klimaty wyraźnie odczuwalne są także w kopenhaskiej hali targowej Torvehallerne, która mieści m.in. liczne stoiska z jedzeniem na wynos. Z kolei na południu Europy, głównie w Hiszpanii, przetrwało wiele targowisk żywności pod dachem bez rozwiniętych w celach komercyjnych funkcji gastronomicznych (Omilanowska, 2007).

O pewnej kosmopolityczności odnowionych Koszyków świadczy menu oferowanych tam potraw, obejmujące szerokie spektrum kuchni narodowych - od meksykańskiej, przez francuską i włoską, po indyjską i japońską. Cecha ta znajduje też spektakularny wyraz w dominującym obco brzmiącym nazewnictwie znajdujących się tam lokali. Mięso i wędliny oferuje nie kto inny jak Crazy Butcher, kotlety można zjeść w Quality Burger Meat, a ryby i owoce morza oczywiście w Port Royal Fish \& Oyster Bar. Wegańskie potrawy serwuje jadłodajnia vegan street food, tapas - bar Sobremese, buritto - Gringo Salsownia, tajskie specjały - Tuktuk, a japońskie - Kago Sushi. Włoskie lody dają naturalnie w Magia d'Italia Gelati Cafe, herbaty sprzedają w Maison de ThE, zaś czekolady w Karmello Chocolatier. A jest jeszcze barek Curry Leaves z własnym piecem tandoori, Soul Food itd. itp. Ale są także, przyznajmy, broniące honoru polskiej kuchni nieliczne knajpki o swojsko brzmiących nazwach: „Kiełbie w Gębie” czy „Siewcy Smaku” (nowy, powracający w nazwie do polszczyzny projekt właścicieli „Pogromców Meatów”).

Krytycy i malkontenci wybrzydzający na odnowioną halę uważają, że mamy tu do czynienia z miejską porażką, z kolejnym przykładem niepotrzebnej gentryfikacji i zmarnowanej szansy. Powiadają, że nie tylko z powodu wyższych cen utraciła ona atut dostępności dla wszystkich i dla każdego, że w odnowionych, wykwintnych i wyrafinowanych wnętrzach nie widać „dawnego", czyli trochę przechodzonej i hardej, tak bardzo arcywarszawskiej starej placówki. Narzekają, że za dużo tu teraz porządku i sterylności, za mało zaś żywiołowej tkanki miejskiej, która normalnie wypełnia podobne przestrzenie.

B. Świątkowska z Fundacji Bęc Zmiana twierdzi, że w odnowionych Koszykach świetnie sprawdziłyby się wszelkie formy tymczasowych targów, np. ze zdrową żywnością, otwartych spotkań dla różnych grup ludzi (Gumowska, 2016). Podobnie uważa 
socjolog G. Makowski, autor książki o Galerii Mokotów (Makowski, 2004), przekonując, że mieszkający w najbliższym sąsiedztwie starzy klienci powinni odzyskać przynajmniej kawałek utraconego miejsca, swojej dawnej przestrzeni. I uzasadnia to w taki sposób: "Zarządcy hali poszli dokładnie w odwrotną stronę niż najnowsze trendy. Teraz idzie się w stronę tzw. life-style shopping centers, otwartych miejsc, gdzie nie ma kontroli, kto wchodzi, kto wychodzi. Wraca się do łączenia funkcji komercyjnych i publicznych. Mam wrażenie, że deweloper zapomniał, że dookoła coś jest" (ibidem).

W ramach przeprowadzonej modernizacji, zdaniem krytyków, zmarnowano więc pewien potencjał na ponowne zaistnienie bardziej publicznej hali targowej, w większym stopniu odpowiadającej pierwotnemu statusowi i tożsamości placówki, ale też wychodzącej naprzeciw współczesnym potrzebom społecznym. Chodzi chociażby o rosnącą ostatnio, także w Warszawie, rzeszę fanów cyklicznych targów rybnych czy śniadaniowych, miłośników żywności ekologicznej i slowfoodowej, jak również jej producentów, którzy swoje niepryskane owoce i warzywa, dobre sery, mleko i pieczywo mogliby tu oferować na wynajmowanych straganach. A takie miejsca, warto pamiętać, niezależnie od swojej rynkowej czy aprowizacyjnej funkcji, tworzą rodzaj istotnego zaczynu miastotwórczego i mają ważne znaczenie społeczne.

A jednak zatłoczone wnętrza zrekonstruowanej hali mogłyby zaświadczać, że nastąpiła jej udana reaktywacja. Oblegane przez ludzi Koszyki znów żyją! - ogłaszają zwolennicy i entuzjaści dokonanej modernizacji. Światowe trendy i wzorce znajdują tu polskie wydanie, globalne i europejskie miesza się z narodowym i lokalnym - argumentują. A to, co kiedyś umarło, znów ożyło, bez blichtru i udawania. „Jest ciągłość, ale w nowej formule architektonicznej” - podsumowuje główny projektant przebudowy hali Mateusz Świętorzecki (Bartoszewicz, 2017). Wielu komentatorów i stołecznych dziennikarzy cieszy się i zachwala tę, ich zdaniem, perfekcyjnie zaprojektowaną nową przestrzeń. Twierdzą, że martwe miejsce przywrócono do życia zmyślnie i z dużym wyczuciem, okazując atencję, respekt i pokorę wobec tradycji. Jak przekonuje D. Bartoszewicz, bynajmniej nie upudrowano trupa, czyniąc z hali mauzoleum lub Frankensteina, tchnięto za to w stare miejsce nowe życie. Zwiewna hala w koronce stalowych podpór, która z tego wyszła, nie udaje przy tym miss świata, nowe stanowi tu tło dla starego i dobrze je uzupełnia (ibidem).

\section{Bardziej swojska Hala Gwardii na placu Żelaznej Bramy}

Hala ta, jako jedna z dwóch sąsiadujących ze sobą i bliźniaczych Hal Mirowskich, o czym już wcześniej wspomniano, powstała na przełomie XIX i XX w. Ten pierwszy w Warszawie kompleks miejskich hal targowych nie tylko w początkach ubiegłego stulecia, ale i przez cały późniejszy dłuższy okres był największą placówką handlową 
w mieście. Następnie jedna z tych hal zaczęła zmieniać swoją pierwotną funkcję. Zaraz po II wojnie znalazła tu siedzibę zajezdnia autobusowa, w latach 50. trenowali w tym miejscu bokserzy z milicyjnego klubu sportowego „Gwardia” (stąd obecna nazwa), a w 1953 r. odbyły się słynne mistrzostwa Europy w boksie, na których Polska zdobyła aż pięć złotych medali. Potem w hali odbywały się koncerty (w tym wielu kultowych zespołów rockowych) i dopiero w latch 90. wróciła do niej działalność handlowa. Jednak przez kilka ostatnich lat stała pusta, po tym jak zbankrutował wynajmujący ją sieciowy supermarket Marcpol.

W 2017 r., po wygranym konkursie, gospodarzem zabytkowej przestrzeni stała się na trzy lata firma CBR Events. Docelowy najemca hali, który przeprowadzi też jej generalny remont, zostanie w wyłoniony w 2020 r. Obecny gospodarz postawił na wielofuncyjność, w istocie trzy filary aktywności: targową, gastronomiczną i kulturalną. Stosownie do tego wewnętrzna przestrzeń obiektu nabrała symbolicznie pełnej trójwymiarowości, na którą składają się: po pierwsze - handel, po drugie - oferta kulinarna oraz po trzecie - koncerty i inne imprezy.

Nawiązującą do bokserskich tradycji tego miejsca, stałą ekspozycją są wielkoformatowe czarno-białe fotografie, przesłaniające podniszczone stropy hali. Przedstawiają one legendarnego trenera pięściarzy Feliksa „Papę” Stamma oraz jego wychowanków olimpijczyków, m.in. Jerzego Kuleja, Mariana Kasprzyka i Zbigniewa Pietrzykowskiego. Na powycieranym linoleum pokrywającym podłogę hali umieszczono także autentyczny ring bokserski, na którym mają się odbywać pokazy pojedynków sportowych, ale który ma służyć także jako scena w wypadku koncertów i innych wydarzeń.

Wśród najemców stoisk - zamiast pośredników - są bezpośredni lokalni producenci żywności. Można kupić m.in. grzyby, sery kozie i pleśniowe (Melt), ryby (znany z targów śniadaniowych „Pan Sum” z Góry Kalwarii), wegańskie potrawy dla sportowców (run Vegan), tradycyjną szynkę wieprzową zwaną kumpiakiem podlaskim, słodkie i wytrawne wypieki, lody rzemieślnicze („Akwarium”), miody, oliwy, lawendowy syrop, piwa z małych browarów, owoce morza i wina. W barkach są dostępne potrawy różnych kuchni świata - od włoskiej (Pizza Lunga), hiszpańskiej (tapas, paella) i gruzińskiej, przez japońską (sushi), hinduską (Tikka Masala), portugalską (TerraßMar) aż po brazylijską (Brasil on the Plate). „Bar Nie Tylko Mleczny” oferuje w przystępnych cenach m.in. lepione na miejscu pierogi, kartacze, móżdżek, tatara, wódkę, a na deser kultowe ciastko warszawskie wuzetkę. Honoru polskiej kuchni bronią także filie lokali istniejących już w innych miejscach Warszawy: „Krowarzywa” i „Kiełbie w Gębie”. Tylko jedna restauracja mająca obsługę kelnerską - „Brasserie Smak” na antresoli - serwuje równocześnie klasyczne dania kuchni francuskiej oraz smaki kuchni polskiej, zwłaszcza przedwojennej Warszawy. 
Hala Gwardii w nowej odsłonie wykazuje pewne podobieństwa do zrewitalizowanej Hali Koszyki. Mieści równie liczne stoiska gastronomiczne (docelowo ma być 40), dochodzą do tego sklepiki zajmujące boksy we wschodniej części budynku (około tuzina) i inne stragany (łącznie ma działać około 60 punktów sprzedaży). Jest jedna duża jadalnia, wspólna przestrzeń do jedzenia: ławki i dziesięcioosobowe stoły, nieprzypisane do konkretnych barów.

Jednak różnic jest więcej. Niewyremontowane kompleksowo wnętrze sprawia wrażenie, jakby obecną funkcję gastronomiczną spełniało od dawna. Oferta kulinarna, oprócz dań podobnych do serwowanych na Koszykach, zawiera też potrawy innego rodzaju i pochodzenia, bliższe choćby tym z Nocnego Marketu przy dawnym Dworcu Głównym. Jest tu znacznie więcej swobody i różnorodności: obok knajpek-konceptów są też stoiska, w których można kupić różne rzeczy nie do jedzenia czy picia, np. wyroby z wikliny, ekologiczne kosmetyki, książki, albumy fotograficzne i warszawskie gadżety (mapy, pocztówki, T-shirty, kubki, klocki składające się w Pałac Kultury), dostępne m.in. w księgarnio-galerii Fundacji Bęc Zmiana.

W sumie więc zrewitalizowana Hala Gwardii to nie są Koszyki-bis, ma ona bardziej swojski klimat i brak jej (albo po prostu ma mniej) pretensjonalności. Nie ma podobnego do Koszyków blichtru, połysku, wypolerowania, nawet cienia snobistycznego zadęcia; ani przez chwilę nie stara się być ekskluzywna. „Przykro mi, Halo Koszyki, ale twoja skromniejsza kuzynka bije cię na głowę" - jednoznacznie oceniała reaktywowaną Halę Gwardii niedługo po jej otwarciu we wrześniu 2017 r. B. Chomątowska (2017). Wydaje się, że właśnie jej jest dużo bliżej, niż Koszykom, do londyńskiego Chelsea Marketu czy madryckiego Mercado de San Miquel, ale też, z drugiej strony, nie próbuje być i nie jest plastikową imitacją zagranicznych targowisk: barcelońskiego Mercado Boqueria czy lizbońskiego Mercado da Ribeira.

Dla klimatu miejsca ważne znaczenie ma prawdopodobnie sąsiedztwo bardzo egalitarnego targowiska pod chmurką przy sąsiedniej Hali Mirowskiej, gdzie w aurze różnych zapachów, kolorów, rozmów i pokrzykiwań mieszają się przybysze z odmiennych światów, które w przestrzeni społecznej nie spotykają się ze sobą zbyt często. Hala Gwardii jest jakby naturalnym przedłużeniem tego bazaru, a jednocześnie komplementarną placówką, gdyż jej oferta jest trochę inna, nieco bardziej wyszukana, $\mathrm{w}$ jakimś stopniu uzupełnia najprostszy bazarowy asortyment.

Niewykluczone, że daje tu o sobie znać wciąż wyczuwalny, unoszący się po latach (z zasypanych gruzem piwnic pod ziemią?) genius loci - duch północnej części śródmieścia, którą przed wojną zajmowała duża dzielnica żydowska. Była to część miasta rozwijająca się bardzo żywiołowo i raczej chaotycznie, bez odgórnie zracjonalizowanego planu, tworząc w efekcie przestrzeń nieco bałaganiarską i nie do końca 
uporządkowaną, zatłoczoną i w sumie dość tandetną, w każdym razie pozbawioną pretensji do supernowoczesności i luksusu.

\section{Odrzucony przeszczep tęczy przed kościołem Najświętszego Zbawiciela}

Przemiany zachodzące w ostatnim okresie na warszawskim placu Zbawiciela stały się swoistym barometrem zmian i nastrojów społecznych. Plac ten, zwany też w skrócie w młodzieżowo-warszawskim slangu Zbawiksem, zamienił się na kilka lat $\mathrm{w}$ arenę potyczki o jakąś formę kontroli czy nawet opanowanie przestrzeni publicznej. Jej rzekome zawłaszczenie przez niejednoznaczny, sporny symbol wywołało radykalne, burzliwe protesty. Pojawienie się w tym miejscu instalacji artystycznej wyobrażającej tęczę odegrało rolę testu na otwartość, spotkanie, pluralizm i różnorodność, cywilizowany dialog publiczny, wzajemny szacunek i tolerancję.

Przestrzeń miejska na tym placu składa się z wielu pochodzących z różnych epok historycznych i nakładających się na siebie organicznie „złogów”, czyli związanych z przeszłością warstw. Pod tym względem to prawdziwy architektoniczny miks i przekładaniec. Elementem dominującym - choć, jak wiadomo, świadomie skrytym po wojnie dla spoglądających na plac od północy z perspektywy ul. Marszałkowskiej - jest tutaj niewątpliwie okazały, trójnawowy kościół pod wezwaniem Najświętszego Zbawiciela. PRL-owskim „złogiem” są z kolei półkoliste socrealistyczne arkady i przylegające do placu budynki MDM-u, a do bardzo niedawna również mieszczący się w jednej ze starych kamienic kultowy bar „Corso”. Niczym relikt Polski Ludowej działał od lat w niezmienionej postaci, co dotyczyło zarówno wystroju lokalu (szare szyby, nieśmiertelna boazeria, lada chłodnicza z garmażem i akwarium), oferty kulinarnej, a nawet unoszącego się tu specyficznego zapaszku piwa i dymu papierosowego z pośledniejszego gatunku tytoniu, który mocno wgryzł się w ściany. Tu można było tanio zjeść i wypić, w menu królowała m.in. pomidorowa z ryżem oraz kotlet mielony z ziemniakami i mizerią jako popularne danie dnia, także np. jajko z majonezem i sałatka warzywna z kwiatkiem z marchwi jako ozdobą na przekąskę. Na jesieni 2016 r. bar jednak zamknięto, bo budynek był w złym stanie technicznym i miasto zdecydowało się wystawić go na sprzedaż, nie chcąc inwestować w remont. Tak zniknął z tutejszej przestrzeni drobny symbol minionej epoki.

Na pełnych obrotach funkcjonuje natomiast przy placu i w jego najbliższej okolicy kilka innych gastronomicznych lokali, m.in. restauracja z całodobowymi śniadaniami, bar sushi, włoska knajpka i kawiarnia, także bar mleczny. Oblegane przez młodzież do bladego świtu, zwłaszcza w letnie weekendy, bardzo modne hipsterskie klubokawiarnie „Charlotte” $\mathrm{i}$ „Plan B” w pierwszej dekadzie XXI w. w istocie zapoczątkowały 
w Warszawie zwyczaj spotykania się i rozmowy na ulicy i przed knajpami, przeniesiony poniekąd z takich europejskich metropolii jak Barcelona czy Berlin. To są już „słoje” najnowszych czasów, suwerennej i demokratycznej, europeizującej się i otwierającej na szerszy świat Rzeczypospolitej.

Ciekawym przypadkiem intruzji nowego, kolorowego elementu w zastany i zmieniający się układ urbanistyczny - którego dominantą jest, jak już wspomniano, świątynia katolicka - okazało się zainstalowanie na samym środku placu wielobarwnej tęczy ze sztucznych kwiatów na metalowym stelażu. Instalacja ta, jako czasowa ekspozycja autorstwa artystki Julity Wójcik, była obecna w tej przestrzeni w latach 2012-2015. W tym okresie była aż sześciokrotnie z rozmysłem podpalana, po raz pierwszy 11 listopada 2012 r. przez demonstrujących w pochodzie pod biało-czerwonymi flagami narodowców, w związku z obchodami polskiego Święta Niepodległości.

Warte tu przypomnienia są wcześniejsze losy tego dzieła. Ta sama instalacja, a w zasadzie połowa łuku tęczy, pierwotnie stanęła w $2010 \mathrm{r}$. w starym katolickim klasztorze w Wigrach, podpierając jego walące się mury i symbolizując tym samym nadzieję na lepszą przyszłość. Następnie, już w pełnej postaci, eksponowana była w 2011 r. przez wiele miesięcy przed Parlamentem Europejskim w Brukseli, w czasie polskiej prezydencji w Radzie UE, symbolizując różnorodność unijnej wspólnoty i jej działań. Ani w Wigrach, ani w Brukseli nie wzbudzała przy tym żadnych kontrowersji.

Katalizatorem napięć i konfliktów tęcza stała się dopiero po umieszczeniu na skwerze placu Zbawiciela w Warszawie. Chociaż nie od razu, bo jeszcze podczas procesji podczas święta Bożego Ciała w 2012 r. bielanki sypały wokół niej kwiatki. Wkrótce jednak przez część ludzi i środowisk została zinterpretowana jako symbol homoseksualizmu, rozwiązłości i środowisk LGBT. Konserwatywny celebryta i podróżnik W. Cejrowski nazwał ją publicznie „pomnikiem grzechu sodomskiego”, przyszły wiceminister obrony w rządzie PiS B. Kownacki - „pedalską tęczą”, zaś „symbolem zarazy” - prezes Młodzieży Wszechpolskiej, a następnie Ruchu Narodowego R. Winnicki, od 2015 r. poseł na Sejm RP5 . Przekonywano, że tęcza to ikona gejów i zboczeńców, mówiono o skandalu i homoagresji, nakręcano spiralę nienawiści, w mediach i internecie rozpętało się prawdziwe piekło. Niektórzy obrońcy tęczy próbowali tymczasem przypominać, że jest ona przecież także pięknym symbolem bibilijnym, znakiem przymierza między Bogiem a Noem i - jak mówi Księga Rodzaju - „Wszystkimi istotami, jakie są na ziemi”. Wszystko to na próżno.

Po kolejnych podpaleniach i rekonstrukcjach tęczy pilnowały dniem i nocą specjalne patrole policyjne, a ona sama stała się pomnikiem „polskiego piekiełka”.

\footnotetext{
5 Na posła został wybrany $\mathrm{z}$ list ugrupowania Kukiz'15, obecnie jest poza tym klubem, ale wciąż pełni rolę lidera Ruchu Narodowego.
} 
Niektórzy proponowali, żeby pozostawić na pamiątkę jej spalony kikut jako wymowny symbol przemocy, braku tolerancji i społecznego podziału. Ponawiane próby odbudowania tęczy w pierwotnej postaci menedżer kultury P. Potoroczyn (2016) określił jako „zwycięstwo siły symbolu nad chamską siłą”. Inni, w tym działacze i zwolennicy Ruchu Narodowego, chcieli ją zastąpić tęczą... biało-czerwoną, nie zważając na fakt, że w rzeczywistości, jak wiadomo, takie zjawisko w postaci dwukolorowej, binarnej w naturze nie występuje.

Z kolei przy okazji Światowych Dni Młodzieży w 2016 r. Instytut Adama Mickiewicza, który wcześniej wspierał tymczasową instalację tęczy, podjął starania, żeby przywrócić ją na trwałe w tym samym miejscu, a jeden z biskupów warszawskiej archidiecezji zadeklarował nawet, że postawi pod nią figurki Noego i zwierzątek. Nic jednak z tego nie wyszło. Wspomnienie i wizerunek płonącej tęczy zaczęły tymczasem żyć własnym życiem. W wypuszczonej na rynek popularnej grze planszowej pt. Czas zaorać socjalizm gracze palą tęczę - jak to objaśnia im załączona instrukcja - jako „symbol międzynarodówki cwelowsko-terrorystycznej”.

Swoiste post scriptum do gorączkowych, nomen omen płomiennych zachowań, reakcji i wydarzeń z lat 2012-2015 dopisała w 2017 r. autorka tego dzieła Julita Wójcik na wystawie Późna polskość. Formy narodowej tożsamości po 1989 r. w warszawskim Muzeum Sztuki Nowoczesnej na Zamku Ujazdowskim. W ostatniej sali tej ekspozycji artystka ustawiła okrągły stól, zbudowany z metalowego stelażu przypominającego szkielet tęczy jej autorstwa, z resztką uratowanych kwiatów. Pod hasłem „Wspólne archiwum tęczy” zaprosiła publiczność do akcji społecznego tworzenia opowieści na jej temat oraz budowania zbiorowej pamięci wokół całego tego artystycznego przedsięwzięcia i jego recepcji.

Wcześniejsze akty wandalizmu, protesty i afera rozpętana wokół instalacji tęczy na placu Zbawiciela skupiły w każdym razie, niczym w soczewce, i na swój sposób pokazały kruchość, słabości i pewną marność warszawskiej i polskiej wspólnoty. W reakcjach tych znalazły nieoczekiwane ujście skrywane głębiej, tłumione na co dzień w podświadomości emocje i obawy. Te symptomatyczne zawirowania ujawniły, jak bardzo pewna część społeczeństwa jest podszyta nie do końca nazwanymi lękiem i agresją wobec rzeczy, które wydają się nie pasować do mniej lub bardziej powszechnie podzielanych wyobrażeń czy tradycyjnych norm. Jak bardzo niektórzy są zdeterminowani i gotowi za wszelką cenę usuwać z pola widzenia i niszczyć coś, co wydaje się im jakieś inne, obce, nacechowane symbolicznie negatywną treścią lub po prostu mało zrozumiałe.

Próba włączenia dodatkowego, emblematycznego obiektu do okrzepłej struktury urbanistycznej - z racji jej centralnego położenia w śródmieściu, można nawet powiedzieć, że więcej: do tożsamości miasta - okazała się w jakimś sensie porażką. 
Pokazała nieumiejętność postrzegania nowych elementów i znaków w przestrzeni publicznej jako wartości, które mogłyby i powinny łączyć wszystkich mieszkańców Warszawy jako członków społeczeństwa, zamiast ich w ostrej formie i bez sensu dzielić.

Że tak być nie musi, mógłby świadczyć inny przykład dość widowiskowego „implantu” w śródmiejski pejzaż stolicy, jakim jest okazała sztuczna palma ulokowana na samym środku ronda de Gaulle’a. Ta zrazu kontrowersyjna instalacja artystyczna, autorstwa Joanny Rajkowskiej, w dość oryginalny i nieoczywisty sposób przypominająca o żydowskich korzeniach Alej Jerozolimskich, po początkowej fali sceptycznych reakcji, zastrzeżeń i głosów dezaprobaty została następnie powszechnie (a w każdym razie szeroko) zaakceptowana, „oswojona” i już na dobre wpisała się w publiczną przestrzeń miejską.

Omówione powyżej przypadki skłaniają w podsumowaniu do sformułowania paru ogólniejszych obserwacji i wniosków. Można wskazać co najmniej kilka tendencji i wyzwań, które zbliżają do siebie zmiany w przestrzeni miejskiej - w szczególności te zachodzące ostatnio w Warszawie - do problemów charakterystycznych dla procesów modernizacyjnych, jakie przebiegają w Polsce w szerszej domenie publicznej po $1989 \mathrm{r}$.

Po pierwsze, trendami pokrewnymi miejskiej gentryfikacji są niewątpliwie różne przejawy urynkowienia, prywatyzacji, ekonomizacji czy finansjalizacji sfery publicznej w skali całego państwa. Zjawiska te dotykają np. sektora usług społecznych (ochrona zdrowia, edukacja itp.), generując nowe podziały warstwowe i obszary społecznego wykluczenia. Następstwa gwałtownego wzrostu stawek czynszowych od najmu nieruchomości, a co za tym idzie także cen w sklepach i punktach usługowych, czego doświadczają mieszkańcy odnawianych dzielnic, bywają analogiczne do niekontrolowanej komercjalizacji różnych dziedzin polityki społecznej.

Po drugie, podobnie jak w miejskich działaniach rewitalizacyjnych, w rozmaitych dziedzinach krajowej polityki publicznej łatwo zauważyć liczne tenedencje naśladowcze, czego wyrazem jest podejmowanie zabiegów imitujących zewnętrzne, zagraniczne wzory i rozwiązania, transfer polityki (policy transfer), zapożyczenia międzykulturowe itp. Na polskich przemianach ostatniego okresu istotnie zaważyły procesy okcydentalizacji i europeizacji, zdynamizowane zwłaszcza akcesją do Unii Europejskiej.

Po trzecie, istotną barierą przedsięwzięć modernizacyjnych na obu poziomach (miejskim i ogólnokrajowym) okazuje się niedostateczny udział społeczeństwa i jego organizacji w programowaniu oraz przeprowadzaniu zmian. Chodzi o wciąż słabą partycypację obywatelską, skutkującą nieadekwatnym rozpoznaniem i uwzględnianianiem 
w praktyce potrzeb mieszkańców. Nie wszystkie możliwości instytucjonalne i prawne $\mathrm{w}$ tej dziedzinie są w pełni wykorzystywane, co dotyczy także ustawy o rewitalizacji z 2015 r., która przewiduje szersze włączanie mieszkańców i organizacji społecznych $\mathrm{w}$ procesy miejskiej odnowy.

Po czwarte, znanym i dość często występującym mankamentem zarówno programów rewitalizacyjnych w miastach, jak i przedsięwzięć reformatorskich w różnych sektorowych politykach publicznych na poziomie całego państwa, jest niedostatek systemowego podejścia, deficyt dostatecznie spójnych i całościowych strategii zmian. Tak jak powierzchowna i punktowa bywa bardzo często odnowa polskich miast, tak też nierzadko mamy do czynienia $\mathrm{z}$ wycinkowym czy wyspowym charakterem polskiej modernizacji.

Po piąte wreszcie, w obu wymiarach daje się czasem zaobserwować naruszanie i niedostatek niezbędnej równowagi między kontynuacją i zmianą, między tym, co stare, a tym, co nowe (Anioł, 2017). Nadmiernie rozległy zakres i zbyt szybkie tempo zmian, ich szokowy charakter, często osłabiają i rozbijają historyczną ciągłość domeny publicznej. Mogą zaburzać nie tylko tradycyjną, zabytkową tkankę materialną, ale i lokalną pamięć zbiorową, a tym samym tożsamość zbiorową (miejską, narodową), poczucie identyfikacji obywateli z miejscem, w którym żyją.

\section{Bibliografia}

Anioł, W. (2016). Kształtowanie przestrzeni miejskiej jako mikrokosmos polityki publicznej. Studia z Polityki Publicznej, nr 2(10).

Anioł, W. (2017). Między starym a nowym. O sposobach modernizowania przestrzeni publicznych. Studia z Polityki Publicznej, nr 2(14).

Anioł, W. (2018). Fabryka, arena, sieć. Trzy paradygmaty w badaniach nad polityka publiczna, w: B. Szatur-Jaworska (red.), Polityki publiczne. Wybrane zagadnienia teoretyczne i metodologiczne. Warszawa: Wydawnictwo UW.

Bartoszewicz, D. (2017). Stołek za Koszyki. Choć należy się tron. Gazeta Wyborcza, 20.01.2017.

Burno, F. (2016). Spektakl i modernizacja. Miasta włoskie w okresie faszyzmu 1922-1945. Warszawa: Fundacja Kultura Miejsca.

Chomątowska, B. (2017). Hala Gwardii lepsza niż Hala Koszyki. Gazeta Wyborcza, 28.11.2017.

Ciarkowski, B. (2017). Odcienie szarości. Architekci i polityka w PRL-u. Łódź: Wydawnictwo UŁ.

Drozda, Ł. (2017). Uszlachetniając przestrzeń. Jak działa gentryfikacja i jak się ją mierzy. Warszawa: IW Książka i Prasa.

Flint, A. (2017). Le Corbusier. Architekt jutra. Warszawa: GWF.

Frąckiewicz, L. (red.) (2004). Wykluczenie, rewitalizacja, spójność społeczna. Katowice-Warszawa: WN Śląsk. 
Franta, A. (2004). Reżyseria przestrzeni. O doskonaleniu przestrzeni publicznej miasta. Kraków: Wydawnictwo Politechniki Krakowskiej.

Gądecki, J. (2012). I love NH. Gentryfikacja starej części Nowej Huty?. Warszawa: IFiS PAN.

Gehl, J. (2009). Życie między budynkami. Użytkowanie przestrzeni publicznych. Kraków: RAM.

Glass, R. (red.) (1964). Aspects of Change. Londyn: MacGibbon \& Kee.

Groyecka, D. (2014). Gentryfikacja Berlina. Od życia na podstuchu do kultury caffe latte. Gdańsk: WN Katedra.

Gumowska, A. (2016). Czekając na bazar. Newsweek, 28.11-4.12.2016.

Hajer, M. i Reijndorp, A. (2001). In Search of New Public Domain: Analysis and Strategy. Rotterdam: NAi Publishers.

Jadach-Sepioło, A. (2009). Gentryfikacja w kontekście rewitalizacji, w: A. Zborowski (red.). Demograficzne i społeczne uwarunkowania rewitalizacji miast w Polsce. Kraków: IRM.

Jastrząb, T. (2004). Przestrzenie publiczne we współczesnej urbanistyce i architekturze. Poznań: Wydawnictwo Politechniki Poznańskiej.

Karpieszuk, W. (2017). Warszawa bardziej dostępna. Gazeta Wyborcza, 24.10.2017.

Le Corbusier (2012). W stronę architektury. Warszawa: FCA.

Ledwoń, S. (red.) (2007). Przestrzeń publiczna - determinanta miasta europejskiego. Gdańsk: Wydawnictwo Politechniki Gdańskiej.

Lees, L., Slater, T. i Wyly, E. (2008). Gentrification. Londyn: Routledge.

Lorens, P. i Ratajczyk-Piątkowska, E. (red.) (2008). Komercjalizacja przestrzeni - charakterystyka zjawiska. Warszawa: Wydawnictwo Urbanista.

Makowski, G. (2004). Świątynia konsumpcji. Geneza i społeczne znaczenie centrum handlowego. Warszawa: Trio.

Merrifield, A. (2016). Nowa kwestia miejska. Warszawa: WN PWN.

Nawratek K. (2008). Miasto jako idea polityczna. Kraków: Korporacja Ha!art.

Olszewski, P. (2010). Przekształcenia przestrzeni publicznych a proces gentryfikacji, w: P. Lorens i J. Martyniuk-Pęczek (red.), Problemy ksztattowania przestrzeni publicznych: 93. Gdańsk: Wydawnictwo Urbanista.

Omilanowska, M. (2016). Wywiad, Gazeta Wyborcza, 4.11.2016.

Peters, B.G. (2015). Advanced Introduction to Public Policy. Cheltenham: Elgar.

Pluta, K. (2012). Przestrzenie publiczne miast europejskich. Projektowanie urbanistyczne. Warszawa: OW Politechniki Warszawskiej.

Potoroczyn, P. (2016). Rozmowa. Gazeta Wyborcza, 23.09.2016.

Sennett, R. (1996). Ciało i kamień. Człowiek i miasto w cywilizacji Zachodu. Gdańsk: Marabut.

Skalski, K. (2009). Rewitalizacja we Francji. Zarządzanie przekształceniami obszarów kryzysowych $w$ miastach. Kraków: IRM.

Skalski, K. (2017). Szanse i zagrożenia programów rewitalizacji, w: L. Frąckiewicz (red.), Wykluczenie. Rewitalizacja. Spójność społeczna. Katowice: Wydawnictwo „Śląsk”. 
Smith, N. (1979). Toward a Theory of Gentrification: A Back to the City Movement by Capital, not People. Journal of the American Planning Association, Vol. 45.

Smith, N. (1996). The New Urban Frontier: Gentrification and the Revanchist City. London: Routledge.

Sudjic, D. (2015). Kompleks gmachu. Architektura władzy. Warszawa: Fundacja Centrum Architektury.

Ustawa o planowaniu i zagospodarowaniu przestrzennym z 27.03.2003 r. Dz. U. 2003, nr 80, poz. 717, z późniejszymi zmianami. 